\title{
Intercropping and its Effect on the Infestation Level by Parlatoria Blanchardii (Hemiptera: Diaspididae) Infesting Date Palm Trees under the field Conditions at Luxor Governorate, Egypt
}

\author{
Bakry MMS $^{1 *}$, Salman AMA ${ }^{2}$ and Moussa SFM ${ }^{1}$ \\ ${ }^{1}$ Department of Scale insects and Mealybugs Research, Plant Protection Research Institute, Egypt \\ ${ }^{2}$ Department of Plant Protection, Sohag University, Egypt
}

Submission: November 24, 2016; Published: January 04, 2017

*Corresponding author: Bakry MMS, Department of Scale insects and Mealybugs Research, Plant Protection Research Institute, ARC Dokii, Giza, Egypt, Tel: 201112383122; Email: md.md_sabry@yahoo.com; profdrahmedsalman@yahoo.com

\begin{abstract}
The aim of this study was to determine the effect of intercropped crops under date palm trees on the infestation level by P. blanchardii (Hemiptera: Diaspididae) infesting seedy Balady date palm leaflets at Esna district, Luxor Governorate during the two years of (2010/2011 and 2011/2012). The obtained results showed that P. blanchardii occurred on all the tested date palm trees all the year round. As well as, the half monthly observations of this insect had four peaks of seasonal activity per year were recorded in all tested date palm trees (only and intercropped). Also, the highest population density of $P$. blanchardii with mean number of 8.51 and 7.08 individuals per leaflet was recorded when Alfalfa plants were intercropped under date palm trees. Followed by sugarcane plants were intercropped under date palm trees when observed the mean number reached ( 8.00 and 6.76 individuals per leaflet) during the two years, respectively.
\end{abstract}

In contrast, the least infestation as average 5.54 and 5.57 individuals per leaflet was observed when banana trees cultivated under date palm trees for two years, respectively. While, the moderate infestation with mean number of 7.29 and 6.36 individuals per leaflet was recorded when date palm trees were single during the first and second years of study, respectively. The results showed that the climatic conditions of autumn and summer months during the first year and winter, spring and summer months during the second year were the optimal for the insect multiplication and build up were recorded on tested date palm trees, since the highest R.M.V.P value was achieved during two years.

The analysis of variance indicated highly significant differences between the population means among the different intercropped crops under date palm trees through the two years. On the other hand, there were insignificant differences among Alfalfa and sugarcane plants were intercropped under date palm trees regarding the level of infestation.

Finally, this work may add some information to be used in integrated pest management programs for controlling white date palm scale insect, P. blanchardii.

Keywords: Parlatoria blanchardii; Seasonal abundance; Intercropping; Date palm trees

\section{Introduction}

Intercropping can be defined as mixed cropping or polyculture is the agricultural practice of the cultivation of two (or more) plant species simultaneously in the same field. In horticulture, the component crops of an intercropping system do not necessarily have to be sown at the same time nor they have to be harvested at the same time, but they should be grown simultaneously for a great part of their growth periods Anil et al. [1], Butts [2].
There are many advantages to intercropping; is that it helps prevent soil erosion from occurring and helps maintain soil fertility and the more efficient utilization of the available resources and the increased productivity Dent and Walton [3], Zhang and Li [4], Langer et al. [5]. It can prevent disease and pests, maintain soil fertility, and utilize the land to its full potential Horwith [6] and Ghosh [7]. Also, provides shelter for natural enemies which in turn feed on the insect pests that 
attack the main crop. The presence of a more diversified flora has a negative effect on the ability of the insect pests to find and use their host plant Dent [8], thus minimizing the need of using expensive and dangerous chemical insecticides Asmanm et al. [9], Sullivan [10] argued that intercropping would be beneficial in pest management, because an increase in the diversity of the plant community tended to increase predator populations. Crops differ in their potential to harbour natural enemies. Differences are brought about, at least in part, by differences in the semiochemicals that are released by the different crops.

Among several pests, infesting date palm trees, parlatoria date scale insect, Parlatoria blanchardii (Targioni-Tozzetti) is considered as pest. At high level of infestation with this scale insect, remarkable damage occurs, resulting in early leaves drop and yield reduction El-Said [11]. Great damages can be done by this scale insect by sucking the plant sap that give low rates of photosynthesis and respiration which leads to curling, yellowing, dropping to leaves and subsequently, cause considerable qualitative and quantitive yield losses and also marketing value of the fruits. A characteristic symptom of infestation by $P$. blanchardii is the appearance and accumulation of its scales on attacked palm parts El-Sherif et al. [12], Blumberg [13].

Little informations were available in the literature concerning the effect of intercropping on the infestation level by P. blanchardii. Therefore, the present work was carried out to clarify the invisible light of the effect of intercropped crops under date palm trees on the infestation level by P. blanchardii infesting seedy Balady date palm leaflets under the field conditions at Esna district, Luxor Governorate during the two years of $(2010 / 2011$ and $2011 / 2012)$. The scope of this study included (population fluctuation, peaks of activity, duration of each peak and rate of monthly variation).

\section{Material and Methods}

This experiment was carried out at Esna district, Luxor Governorate to study the simultaneous effect of intercropped crops under date palm trees on the infestation level of $P$. blanchardii infesting seedy Balady date palm leaflets under the field conditions at Esna district, Luxor Governorate during the two years of (2010/2011 and 2011/2012). However, date palm plantations which chosen for this study did not receive any chemical treatment through the present investigation.

The tested date palm trees were sorted into four groups as follows:

1. Date palm trees only (single crop).

2. Date palm trees intercropped with Sugar cane plants.

3. Date palm trees intercropped with Alfalfa plants.

4. Date palm trees intercropped with Banana trees.

Four palms of seedy Balady variety each group of almost similar and as uniform as possible in size, age (5 years), shape, height, vegetative growth and received the normal agricultural practices without pruning the fronds and application any chemical control measures before and during the period of investigation, were randomly chosen for sampling which was practiced at half-monthly intervals were selected for carrying out this study which started from the first of September, 2010 to the end of August, 2012. The sample size (10 leaflets) was taken from every palm. Regular half-monthly samples were collected and immediately transferred to laboratory in polyethylene bags for inspection by the aid of stereo-microscope. Number of alive insects on upper and lower surfaces of leaflets on date palm trees were examined, counted and recorded together opposite to each inspected date. Also, the rate monthly variation in the population (R.M.V.P) was calculated according to the formula reported by Serag-El-Din (1998):

$$
\text { (R.M.V.P) }=\frac{\text { Av. count of insect at a month }}{\text { Av. count given at the preceding month }}
$$

The data were subjected to analysis of variance (ANOVA) and means were separated at $\mathrm{P} \leq 0.05$ using least significant difference test.

\section{Results and Discussion}

\section{Seasonal fluctuations in population}

The half-monthly counts of $P$. blanchardii on tested date palm trees at Esna district, Luxor Governorate were recorded through the two successive years (2010/2011 and 2011/2012) are graphically illustrated in Figure 1.
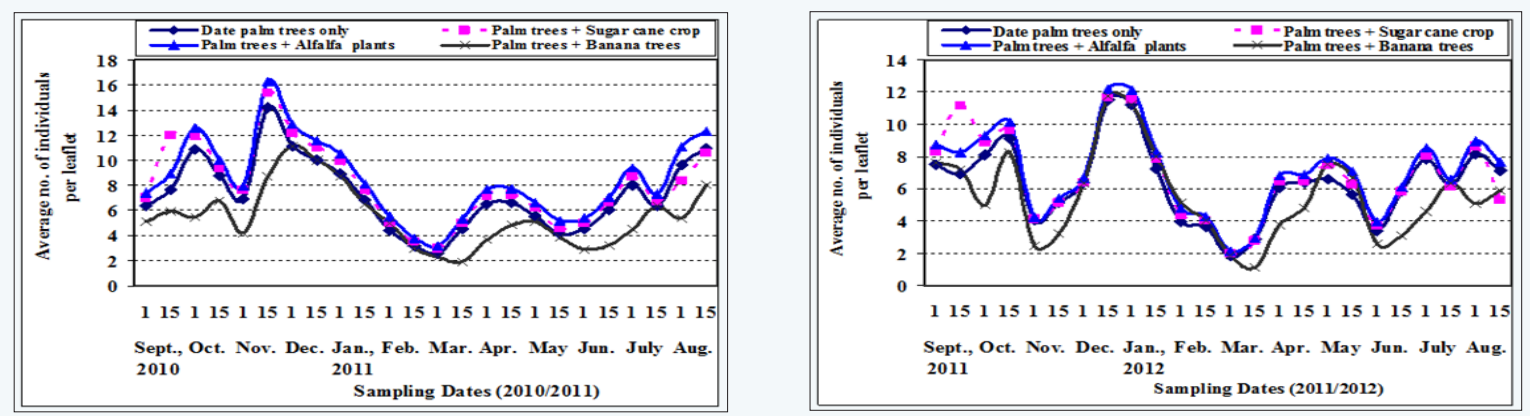

Figure 1: Seasonal abundance of the parlatoria date scale insect, $P$. blanchardii on the leaflets of tested date palm trees at Esna district, Luxor Governorate during the two successive years (2010/2011 and 2011/2012). 
The obtained results showed that half monthly observations of this insect had four peaks of seasonal activity per year were recorded in all tested date palm trees (only and intercropped) are illustrated in Figure 1.

Table 1: Date and population density of total population peaks of $P$. blanchardii on tested date palm trees during the two successive years (2010/2011 and 2011/2012).

\begin{tabular}{|c|c|c|c|c|c|c|c|c|c|}
\hline \multirow{3}{*}{ Peaks } & \multirow{3}{*}{ Year } & \multicolumn{8}{|c|}{ Tested date palm trees } \\
\hline & & $\begin{array}{l}\text { Date palm } \\
\text { trees only }\end{array}$ & & $\begin{array}{c}\text { Palm trees } \\
+ \text { Sugar } \\
\text { cane }\end{array}$ & & $\begin{array}{l}\text { Paint trees } \\
+ \text { Alfalfa }\end{array}$ & & $\begin{array}{l}\text { Palm trees } \\
\text { + Banana }\end{array}$ & \\
\hline & & Date & $\begin{array}{c}\text { Mean } \\
\text { number of } \\
\text { individuals } \\
\text { / leaflet }\end{array}$ & Date & $\begin{array}{c}\text { Mean } \\
\text { number of } \\
\text { individuals } \\
\text { / leaflet }\end{array}$ & Date & $\begin{array}{c}\text { Mean } \\
\text { number of } \\
\text { individuals } \\
\text { / leaflet }\end{array}$ & Date & $\begin{array}{c}\text { Mean } \\
\text { number of } \\
\text { individuals } \\
\text { / leaflet }\end{array}$ \\
\hline \multirow[t]{2}{*}{1} & First & Oct., $1^{\text {st }}$ & 10.9 & Sept., $15^{\text {th }}$ & 12 & Oct., 1" & 12.6 & Oct., $15^{\text {th }}$ & 6.8 \\
\hline & Second & Oct., $15^{\text {th }}$ & 9.14 & Sept., $15^{\text {th }}$ & 11.1 & Oct., $15^{\text {th }}$ & 10.1 & Oct., $15^{\text {th }}$ & 8. 26 \\
\hline \multirow[t]{2}{*}{2} & First & Nov., $1: 5^{\text {th }}$ & 14.2 & Nov., $15^{\text {th }}$ & 15.4 & Nov., $15^{\text {th }}$ & 16.3 & Dec. sit & 11.2 \\
\hline & Second & Dec., $15^{\text {th }}$ & 11.5 & Dec., $15^{\text {th }}$ & 11.7 & Dec., $15^{\text {th }}$ & 12.2 & Dec., $15^{\text {th }}$ & 11.7 \\
\hline \multirow[t]{2}{*}{3} & First & April, $15^{\text {th }}$ & 6.6 & April, $15^{\text {th }}$ & 7.3 & April, $15^{\text {th }}$ & 7.8 & May, 1" & 5.2 \\
\hline & Second & May, 1' & 6.6 & May, $13^{\text {th }}$ & 7.4 & May, 1" & 7.9 & May, 1" & 7.53 \\
\hline \multirow[t]{2}{*}{4} & First & Aug., $15^{\text {th }}$ & 11 & Aug., $15^{\text {th }}$ & 10.6 & Aug., $15^{\text {th }}$ & 12.3 & Aug., $15^{\text {th }}$ & 8 \\
\hline & Second & Aug., 1" & 8.15 & Aug., 1" & 8.63 & Aug., 1" & 8.96 & July, 15” & 6.35 \\
\hline
\end{tabular}

Concerning, the data in Table 1 , revealed that the second peak of activity of $P$. blanchardii was higher in population size as compared with the others peaks of activity were recorded on all the tested date palm trees during the two years. Followed by the first and fourth peaks were intermediate. However, the least one was observed on third peak was observed in all the tested date palm trees in both years. Also, the differences in the dates of each peak of activity and its population varies from peak to another, which may be due to differences in the environmental conditions and other factors. Dent stated that the seasonal phenology of insect numbers, the number of generations, and the level of insect abundance at any location are influenced by the environmental factors at that location.

These results were coincided with those obtained by Salama [14] in Wadi El-Natroun, Egypt, found that P. blanchardii on date palm were the most abundance in October. Kehat et al. [15] in Israel stated that the populations of P. blanchardii on date palms were found to increase substantially in autumn. Saad [16] in Egypt, found that a significant difference in the insect activity during autumn and winter.

Hussain [17] at Bahria oases showed that, the population density of $P$. blanchardii on date palms had three peaks in October, March and July. Eraki [18] in Egypt, reported that that P. blanchardii had four peaks, which was recorded in the beginning of March, beginning of June, beginning of September and beginning of December per year. Also, stated that the environmental conditions during in December were suitable period for population growth, as well as these conditions were to be optimum in December for P. blanchardii. Youssef [19] at Baltim region, Kafr El- Sheikh Governorate, Egypt, reported that insect had three distinct peaks during the year of study, the highest peak was found in October, the second in March and the smallest third one in June. 
Table 2: Effect of intercropped crops under date palm trees on the infestation rate of $P$. blanchardii infesting seedy Balady date palm leaflets during seasons of year at Esna district, Luxor Governorate during the two years of (2010/2011 and 2011/2012).

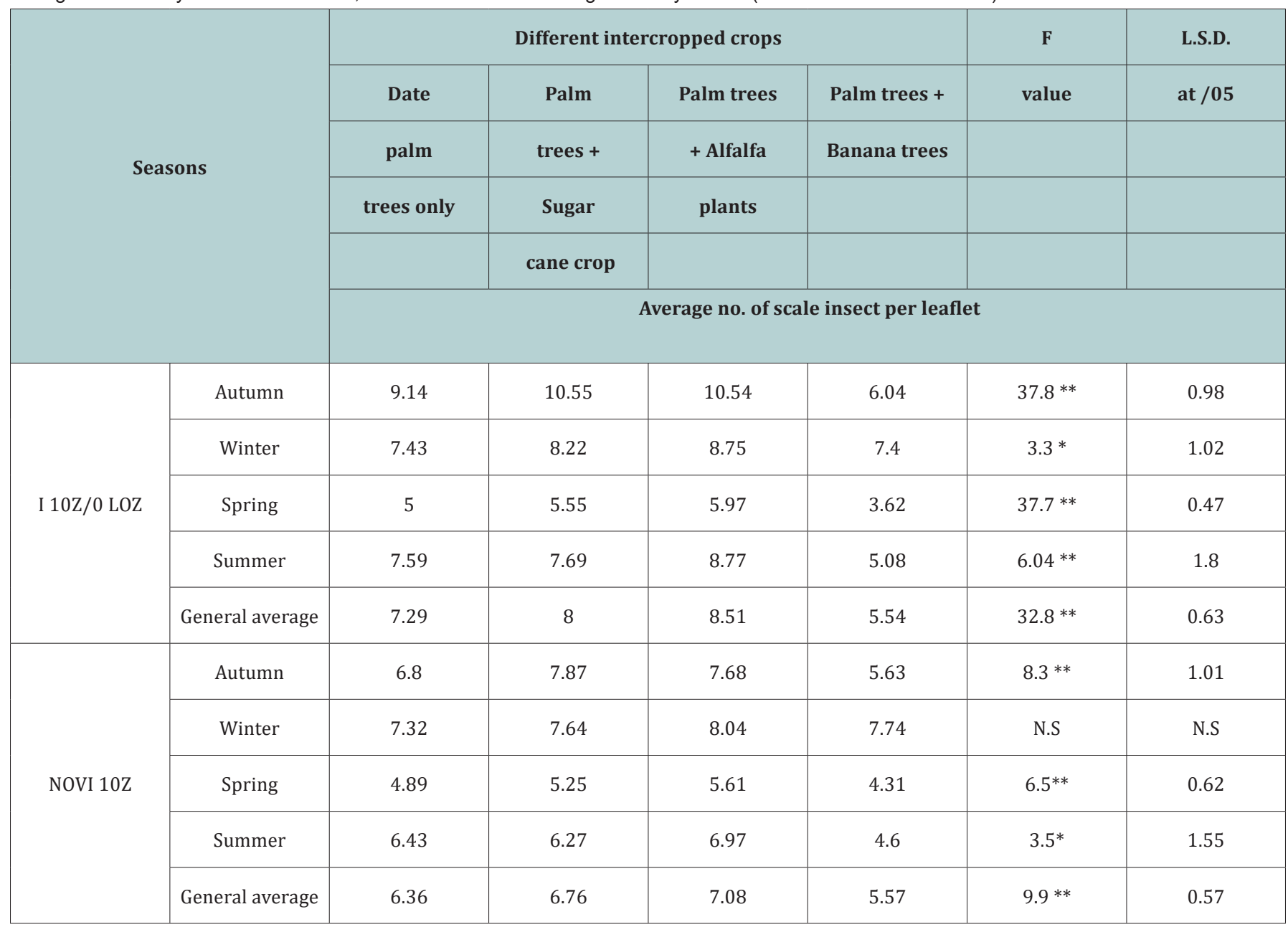
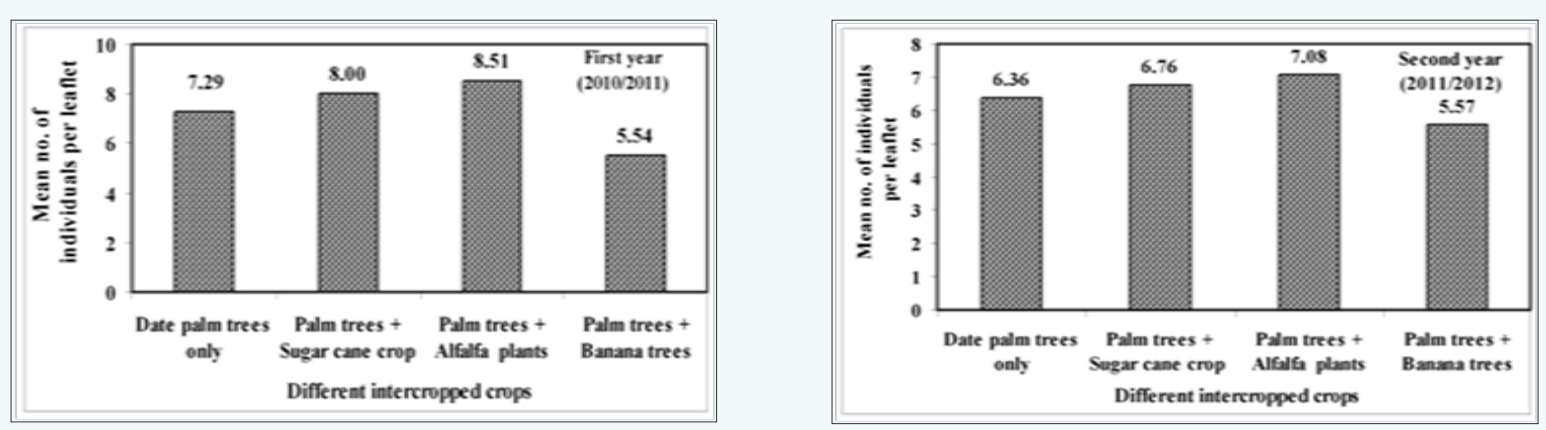

Figure 2: Effect of intercropped crops under date palm trees on the infestation rate of $P$. blanchardii infesting seedy Balady date palm leaflets at Esna district, Luxor Governorate during the two years of (2010/2011 and 2011/2012). The population density graphed in this figure represents the general average of 24 counts all over the year.

Results as represented in Table 2 and illustrated in Figure 2, showed that the highest population density of P. blanchardii with mean number of 8.51 and 7.08 individuals per leaflet was recorded when Alfalfa plants were intercropped under date palm trees. Followed by sugarcane plants were intercropped under date palm trees when observed the mean number reached (8.00 and 6.76 insect per leaflet) during the $1^{\text {st }}$ and $2^{\text {nd }}$ years, respectively. In contrast, the least infestation as average 5.54 and 5.57 individuals per leaflet was observed when banana trees cultivated under date palm trees for two years, respectively. While, the moderate infestation with mean number of 7.29 and 6.36 individuals per leaflet was recorded when date palm trees were single during the $1^{\text {st }}$ and $2^{\text {nd }}$ years of study, respectively, Table 2 and illustrated in Figure 2.

The analysis of variance indicated highly significant differences between the population means among the different 
intercropped crops under date palm trees through the two years when the comparison were directed for the combined effect on all seasons of the whole year. On the other hand, there were insignificant differences among Alfalfa and sugarcane plants were intercropped under date palm trees regarding the level of infestation (Table 2).

As regarding, the seasons of year in Table 2 the statistical analysis of data, revealed that there were highly significant differences between different intercropping crops under date palm trees in all seasons of year when the comparison were directed for each season separately, except during the winter season was significant was recorded during the first year (2010/2011).

While, the second year (2011/2012), showed that highly significant differences between different intercropping crops under date palm trees in autumn and spring, while, significant in the summer, and insignificant in the winter, Table 2. Also, in the same table, the mean total population density of insect in the $1^{\text {st }}$ year was higher in comparison to the $2^{\text {nd }}$ year of study, which may due to the influence of favorable factors (such as environmental conditions and others factors, ..........etc.). These results are almost in agreement with those of Metwally et al. [20], however with different insect species and different host also performed the effect of different intercropping systems between plants on pest populations and weight of yield. Hassan [21] in Nigeria found that cowpea + sorghum intercrop reduced aphid (Aphis craccivora) population significantly compared to sole cowpea crop. El-Fakharany et al. [22] in Egypt, reported that the rate of infestation was higher in the sole sugar beet plants than in those intercropped with faba bean, maize and cabbage plants which caused reduction of sucking pests and Pegomyia mixta eggs in the two seasons. The intercropping of faba bean plants led to higher infestation rate of $P$. mixta larvae in the two seasons and Cassida vittata (larvae, pupae and adults) in the first season.

\section{Rate of monthly variation (R.M.V.P.) in the population of the parlatoria date scale insect, P.blanchardii on different tested date palm trees}

The monthly variation rates in the population of total population of $P$. blanchardii were calculated (Table, 2). The rate of monthly variation in the population is considered an indicator to the favorable month for insect activity expressed as monthly the increase of this insect population through the year. When R.M.V.P. is $>1$ it means more activity, $<1$ means less activity and $=1$ means no change in the population density during the two successive months Bakry [23].

It was shown as recorded in Table 2 that the favorable times of annual increase for total population, it could be concluded that the favorable times for annual increase appeared to be in October, November, December, April, June, July and August during the first year $(2010 / 2011)$, when the rates of monthly variation were $>1$ was recorded when this insect occurred on date palm trees only, date palm trees + sugar cane plants and date palm trees + alfalfa plants. While, it took place in October, November, December, April, May, July and August, when the rates of monthly variation were higher than 1 when this insect observed on date palm trees + banana trees (Table 1).

Moreover, the rates of monthly variation (R.M.V.P) during the second year (2011/2012), showed that the favorable times for annual increase for total population, seemed in months (October, December, January, April, July and August), (December, January, April, May and July), (October, December, January, April, May, July and August) and (December, January, April, May, July and August) were occurred on date palm trees only, date palm trees + sugar cane plants, and date palm trees + alfalfa plants and palm trees + banana trees, respectively and both of them are higher than $>1$.

Climatic conditions of autumn and summer months during the first year and winter, spring and summer months during the second year were the optimal for the insect multiplication and build up were recorded on tested date palm trees, since the highest R.M.V.P value was achieved during two years.

This result was agreeable with Laudeho and Benassy [24] in Mauritania, stated that the density and severity of infestation with $P$. blanchardii is affected by microclimate conditions. High temperature combined with wind and low humidity was very effective for the survival of the crawlers. These results were coincided with those obtained by Kehat et al. [15], Saad [16], Eraki [18], they reported that that found that a significant difference in the insect activity during autumn and winter. Swaminathan and Verma [25] found the infestation with P. blanchardii on date palm trees sets in December on wards on leaflet from basal tissues, upwards reached its peak in net October.

The difference in our results, which may be due to many reasons such as the differences in the region, soil type, mineral elements of soil, normal agricultural practices (such as fertilization, irrigation, planting spaces, density of plants and difference in canopy size), natural enemies and other undetermined and unconsidered factors [26].

Finally, this work may add some information to be used in integrated pest management programs for controlling date palm insects.

\section{References}

1. Anil, Park, Phipps, Miller (1998) Temperate intercropping of cereals for forage: A review of the potential for growth and utilization with particular reference to the UK. Grass Forage Science 53(4): 301-317.

2. Butts PA (2003) Influence of intercropping canola or pea with barely on assemblages of Ground beetles (Coleop: Carabidae). Environ Entomology 32 (3): 535-541.

3. Dent DR, Walton MP (1997) Methods in ecological and agricultural entomology. CAB international, pp. 387.

4. Zhang F, Li L (2003) Using competitive and facilitative interactions in intercropping systems enhances crop productivity and nutrient-use efficiency. Plant Soil 248(1): 305-312. 
5. Langer V, Kinane J, Lyngkj RM (2007) Intercropping for pest management: The ecological concept. In: Koul $O$ and Cupreus GW (Eds.), Ecologically Based Integrated Pest Management, CABI Publishing, Wallingford, UK.

6. Horwith B (1985) A role for intercropping in modern agriculture Bioscience 35(5): 286- 291.

7. Ghosh PK (2004) Growth, yield, competition and economics of groundnut-cereal fodder intercropping systems in the semiarid tropics of India. Field Crops Research 88(2-3): 227-237.

8. Dent D (1991) Insect Pest Management. (2 ${ }^{\text {nd }}$ edn), CABI Bioscience, New York, USA, p. 1-24.

9. El-Said MI (2000) Survey of date palm insects in North Sinai with special reference to the ecology and biology of the species, Parlatoria blanchardii (Targioni- Tozzettii), supper family Coccoidea. p. 97.

10. Salama HS (1972) On the Population Density and Bionomics of Parlatoria blanchardii (Targioni -Tozzettii) and Mycetaspis personatus (Comstock) (Homoptera: Coccoidea). Zeitschrift für Angewandte Entomologie 70(4): 403-407.

11. El-Said MI (2000) Survey of date palm insects in North Sinai with special reference to the ecology and biology of the species, Parlatoria blanchardii (Targioni- Tozzettii), supper family Coccoidea. p. 97.

12. El-Sherif SI, Elwan EA, Abd-El-Razik MIE (2001) Ecological observations on the date palm parlatoria scale, Parlatoria blanchardii (Targioni- Tozzettii) (Homoptera: Diaspididae) in north Sinai, Egypt. Second International Conference on Date Palms, pp.223.

13. Blumberg D (2008) Date Palm Arthropod Pests and Their Management in Israel. Phytoparasitica 36(5): 411-448.

14. Salama HS (1972) On the Population Density and Bionomics of Parlatoria blanchardii (Targioni -Tozzettii) and Mycetaspis personatus (Comstock) (Homoptera: Coccoidea). Zeitschrift für Angewandte Entomologie 70(4): 403-407.

15. Kehat M, Swirski E, Blumberg D, Greenberg S (1974) Integrated control of date-palm pests in Israel. Phytoparasitica 2(2): 141-149.

16. Saad AGA (1980) Studies on palm trees insects belonging to Coccoidea in Egypt. PhDThesis, Fac Agric, Al-Azhar Univ, Cairo, Egypt.
17. Hussain AE (1996) Comparative study on distribution and seasonal abundance of date scale, Parlatoria blanchardii (Targioni- Tozzettii). Populations in Giza and Bahria Oases regions. Bull Ent Soc Egypt 74: 54-60.

18. ERaki MM (1998) Ecological studies on some scale insects infesting date palm trees. Al-Azhar Univ, Egypt, pp. 127.

19. Youssef AE (2002) Ecological studies on date palm scale insect, Parlatoria blanchardii (Targ.) on two date palm varieties at Kafr ElSheikh Governorate. J Agri Sci (27): 1291-1299.

20. Metwally MAS, El-Naggar ME, El-Khateeb HM, Abou-Zaid AMM (2008) Effect of intercropping of some aromatic plants on the infestation levels of Tetranychus urticae Koch to cucumber plants and its resulted yield in both open and green house conditions. Egypt J Agric Res 86(1): 259-268.

21. Hassan S (2009) Effect of variety and intercropping on two major cowpea [Vigna unguiculata (L.) Walp] field pests in Mubi, Adamawa State, Nigeria. J Horticult Forest 1(2): 104-106.

22. El-Fakharany SKM, Samy MA, Ahmed SA, Khattab MA (2012) Effect of intercropping of maize, bean, cabbage and toxicants on the population levels of some insect pests and associated predators in sugar beet plantations. The Journal of Basic \& Applied Zoology 65(1): 21-28.

23. Bakry MMS (2009) Studies on some scale insects and mealybugs infesting mango trees in Qena Governorate. Fac Agric Minia Univ, pp. 204.

24. Laudeho Y, Benassy C (1969) Contribution a letude del ecologie de Parlatoria blanchardii (Targioni-Tozzettii) on Adrar Mauritania. Fruits 24: 273-287.

25. Swaminathan R, Verma SK (1991) Studies on the incidence of date palm scale, Parlatoria blanchardii (Targioni- Tozzetti) in western Rajasthan. Journal article Entomon 16(3): 217-221.

26. Erag El-Dien AM (1998): Ecological and biological studies on the Chrysomphalus dictyospermi and Coccus hesperidium. MSc Thesis, Fac Sci, Cairo Univ, Egypt, pp. 212.

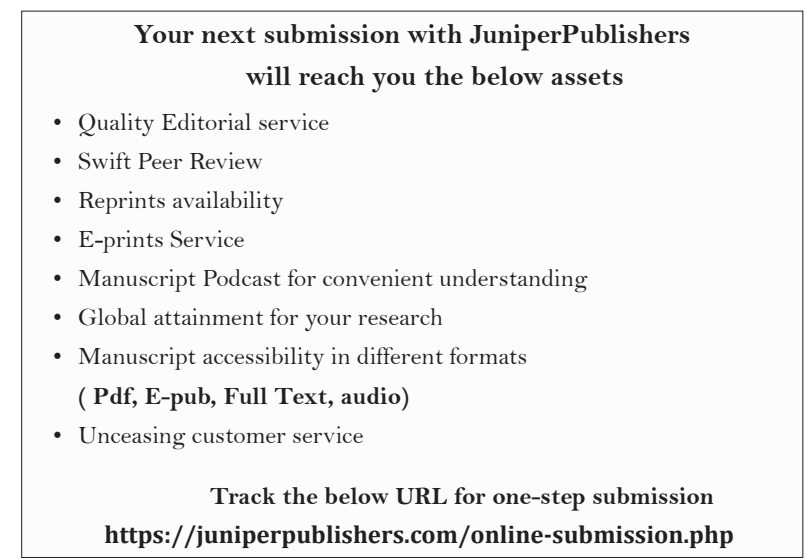

